\title{
UTILIZATION OF SPARES LAND USING HYDROPONIC PLANTING METHOD TO IMPROVE FAMILY WELFARE IN ANGGADITA VILLAGE, KARAWANG
}

\author{
Fransisca Listyaningsih, Annisa Hakim, Nurul Hidayah, and Zamri \\ Universitas Mercu Buana Jakarta, Indonesia \\ Universiti Sains Malaysia, Malaysia.
}

\begin{abstract}
Sukamulya Hamlet, Anggadita Village is one of the hamlets located in Klari District, Karawang Regency, West Java. Anggadita Village is located in a densely industrial and residential area so it is very arid. The density of settlements around the village of Anggadita Karawang and the lack of land that can be used to plant crops is a problem of the lack of interest of residents to plant. Hydroponic cultivation is a solution to the problem of limited land for the residents of Anggadita Village, Karawang. By providing training to residents it is hoped that residents around the village of Anggadita Karawang can continue to increase their hydroponic plant production so that the production of their hydroponic plants can be increased and can be consumed by themselves so that household expenses can be saved. The method used is training in how to plant and care for plants by applying fertilizers so that the yield of hydroponic plants is increasing. The training was carried out by practicing how to plant hydroponics, followed by visits to the homes of residents to evaluate the growth of the plants.
\end{abstract}

Keywords: Hydroponics, Limited Land, Family Welfare

\section{PRELIMINARY}

\subsection{Background}

Improvement of family welfare can be carried out through the cultivation of vegetables and potted fruit plants in the yard. In urban areas, especially in arid industrial areas, it is difficult to get fertile soil for cultivation media so that hydroponic cultivation is a viable alternative. Hydroponics as a form of crop cultivation in urban areas is aimed at fulfilling the fulfillment of family nutrition from vegetables and fruit in urban areas and saving household expenses. Hydroponics is expected to increase family income and efficiency in land use and can increase harmony and comfort and improve the quality of the city's environment.

In order to help the community to improve the optimization of the use of a narrow yard, an effort should be made to improve the usability of the yard. The expected benefit is that the community can utilize the yard by planting vegetables in the yard in a hydroponic manner, wherein the yard is kept clean because it does not use soil and plants grow well because the nutrients needed are available.

\subsection{Focus on Community Service}

Sukamulya Hamlet, Anggadita Village, Klari, Karawang is located in an industrial area. The settlement around Sukamulya Hamlet has a narrow yard. This narrow yard will limit the community's activities to reforest and cultivate vegetables and fruits that can support the improvement of family nutrition.

The narrowness of available land in settlements, the lack of public knowledge to optimize the benefits of the yard with limited area and the lack of information about hydroponic farming methods resulted in hydroponic farming methods not yet widely known. The public does not yet know that the hydroponic method not only functions to take advantage of narrow and limited land but also can improve nutrition and family welfare.

\subsection{Justification And Targets}

Cultivating without using soil media means that plants' needs for mineral substances (nutrients) are met through water. All mineral elements (nutrients) needed for plants are still fulfilled, not eliminated or reduced. The same is true for plants with respect to light and temperature. Plants need light, temperature and humidity in accordance with the original so that plants can grow well. 
This hydroponic cultivation method has many advantages, namely the success of plants to grow and produce more guaranteed, more practical maintenance and more controlled pest control, the use of fertilizer is more efficient (efficient), dead plants can be easily replaced with new plants, more working methods economical and have standardization, can grow faster and cleaner (not dirty) and not easily damaged, higher production results and are continuous, the selling price of hydroponic products is higher, some types of plants can be cultivated out of season, there is no risk dependence on natural conditions (floods, drought, erosion) and can be done on land or limited space.

Based on the description, the cultivation of hydroponic plants needs to be socialized to Anggadita Village residents. Besides being used to utilize limited land for reforestation, this training is expected to be able to improve the economy of the citizens. The results of the cultivation of hydroponic plants can be consumed alone so that the household economy becomes more efficient.

\subsection{Identification Of Problems}

From the identification of these problems, several important points were obtained, including:

1. Anggadita villagers have not used the yard or narrow land to do hydroponic planting.

2. Anggadita villagers do not yet know how to plant hydroponics properly and the results can be consumed by themselves so that household expenditure becomes more efficient.

\subsection{Relevance}

Community service is expected to contribute to increasing the production of hydroponic plants by eradicating pests and diseases in hydroponic plants. With the increased production of hydroponic plants, it is expected to help improve the family's economy by consuming hydroponic crops by itself so that household spending becomes more efficient.

\section{METHOD}

The method of implementing the activity is divided into 4 parts, namely:

\subsection{Pre-Activity}

At the pre-activity stage, a visit to the training location was held and a discussion about the technical implementation of the activity with leaders and community leaders in the village of Anggadita, Karawang, preparation of training materials, tools and materials as well as setting targets for the training participants.

\subsection{Directing}

The briefing is carried out, namely giving a general description of:

1. Grow hydroponically in limited land

2. Increasing family income and economy through hydroponics

\subsection{Training Implementation}

The training is carried out in the following stages:

1. How to plant using the hydroponic method

2. How to care for hydroponic plants

\subsection{Post-Test dan Quesionnaire}

Post-Test activities are carried out after the training activities are given. Residents already know how to grow using the hydroponic method and take care of hydroponic plants and the results of the plants can be consumed by themselves, thereby increasing the income and family economy. The questionnaire was conducted to obtain information about the results of the training program, also to include feedback from the training participants that was very helpful in improving the training. 


\section{RESULTS AND DISCUSSIONS}

\subsection{Results}

\begin{tabular}{|c|c|c|}
\hline No & Output Type & Performance Indicator \\
\hline 1 & Scientific publications in ISSN jurnals/proceeding 1) & \\
\hline 2 & Publication in print/online/repository media 6) & \\
\hline 3 & $\begin{array}{l}\text { Increasing competitiveness (increasing quality, quantity, and } \\
\text { value added of goods, services, product diversification, or } \\
\text { other resources 4) }\end{array}$ & \\
\hline 4 & $\begin{array}{l}\text { Improvement of science and technology in society } \\
\text { (mechanization, IT, and management) 4) }\end{array}$ & \\
\hline 5 & $\begin{array}{l}\text { Improvement of community values (cultural, social, } \\
\text { political, security, security, education, health) 2) }\end{array}$ & Reached \\
\hline 6 & Publication in international journal 1) & Reached \\
\hline 7 & $\begin{array}{l}\text { Services, social engineering, methods or systems, products / } \\
\text { goods 5) }\end{array}$ & Reached \\
\hline 8 & New Innovation atau TTG 5) & \\
\hline 9 & $\begin{array}{l}\text { Intellectual property rights (Patents, simple patents, } \\
\text { copyrights, trademarks, trade secrets, industrial product } \\
\text { design, protection of plant varieties, protection of integrated } \\
\text { circuit toography designs) 3) }\end{array}$ & \\
\hline 10 & Book with ISBN 6) & \\
\hline
\end{tabular}

\subsection{Discussions}

The initial phase carried out by the community service team before conducting training and counseling was a survey and interview of residents in the Sukamulya Hamlet, Anggadita Village, Karawang. The next stage is making agreements with residents through the kelurahan, RT management and PKK management. After an agreement was made with residents and the kelurahan, RT and PKK, the next step was to make an invitation and distribute it to all residents in the Sukamulya Hamlet, Anggadita Village, Karawang. Training participants are citizens who are representatives determined by the head of the RT or RW leader. This dedication activity took the form of training and hydroponic plant cultivation practices held at Anggadita Village Hall, Karawang.

The next stage is making agreements with residents through the kelurahan, RT management and PKK management. After an agreement with the residents and the village, RT and PKK, the next step was to make an invitation and distribute it to all residents in the village of Anggadita Karawang. The trainees were a number of residents of Desa Anggadita Karawang. This dedication activity took the form of training and farming practices using the hydroponic method carried out at the Citizen Hall of RT 25, Anggadita Village, Karawang.

This hydroponic farming training and extension program was opened by the Head of Anggadita Village by giving a speech about planting with the hydroponic method, the results of which can be consumed by themselves so that family expenses can be more efficient and the family economy can be increased. The opening of this activity was also attended by the lecturer implementing the activity.

After the opening ceremony, it was immediately continued with counseling and hands-on practice on how to grow crops using the hydroponic method by using seedling containers and vegetable seedlings provided by the PPM team or by using used items such as used bottles and cans.

Monitoring of the success of this pest eradication is carried out by direct observation to the field by the PPM team for approximately 30 days. Review 3 days after the training, each participant observed his plant growth on the third day, which began to grow plant seeds. Review after 10 days, the plants begin to grow and have many leaves, but there is a problem that is faced by some of the plants whose leaves have holes and change color to yellow or black. This change is caused by pests or diseases that attack the plant. Eradication of pests or diseases is based on damage to plants. 
The final stage of this activity is the assessment of crop yields. After the plants are 30 days old, the PPM team will assess and judge the results of the participant's hydroponic plants. Participants who have fertile and healthy hydroponic plants will be declared champions.

\section{CONCLUSIONS AND RECOMMENDATION}

Community service activities with the theme of empowering women in helping the family economy through hydroponic farming activities in the RT 25 area of Anggadita Village, Karawang run well. This can be seen from the enthusiasm of residents in participating in training activities because most of the participants do not understand and know how to plant using hydroponic methods and care for hydroponic plants. This activity can also be a provision for residents to continue to improve the yield of hydroponic plants and the results can be consumed by themselves so that family expenses become more efficient.

\section{REFERENCE}

Hendro Wibowo. Panduan Terlengkap Hidroponik. Gramedia.

Heru Agus Hendra dan Agus Handoko. Bertanam Sayuran Hidroponik Ala Pak Tani. Agro Media Pustaka.

Latifah, E., Boga, K., and Maryono, J. (2014). Pengenalan Model Kebun Sayur Sekolah untuk Peningkatan Konsumsi Sayuran bagi Para Siswa di Kediri-Jawa Timur. Agriekonomika 3(1): 34-44.

Randi Delmar Zakaria. Budi Daya Hidroponik Pemula.

Roidah, I. S. (2015). Pemanfaatan Lahan dengan Menggunakan Sistem Hidroponik. Jurnal Bonorowo 1(2): 4349.

Siregar, M. (2018). Respon Pemberian Nutrisi Abmix pada Sistem Tanam Hidroponik Terhadap Pertumbuhan dan Produksi Tanaman Sawi (Brassica Juncea). Jasa Padi 2(2): 18-24 